IKONOMIKA: Journal of Islamic Economics and Business

Volume 2, No 2 (2017)

ISSN: 2527-3434 (PRINT) - ISSN: 2527-5I43 (ONLINE)

Page: I49-I6I

\title{
MURABAHAH FINANCING AND ITS IMPLEMENTATION FOR THE ECONOMIC EMPOWERMENT OF THE UMMAH
}

\author{
Abdul Rahmat \\ Gorontalo State University \\ abdulrahat@ung.ac.id
}

\begin{abstract}
The discussion in this research is conducted to know the implementation of supervision of shahibul maal done in reducing the financing problem. In accordance with the provisions of Bank Indonesia that the amount of non-performing financing disbursed shall not exceed 5\%. While on average per year the number of shahibul maal financing problem is greater than $5 \%$, resulting from $5 \%$. To be able to perform the rescue of troubled financing, some efforts need to be done such as rescheduling to allow leeway to Shahibul Maal to pay the financing that has been due by delaying the maturity date. Then re-arrange the financing requirements to strengthen the bargaining position with the customer by reviewing the contents of the financing agreement when necessary plus or minus. And improve the funding structure (recapitulation) and business organization, help improve the condition and financial liquidity of Shahibul Maal. Thus little by little Shahibul Maal was able to pay off his troubled financing.
\end{abstract}

Keywords: Monitoring, Murabahah Financing, Troubled Financing

\begin{abstract}
Abstrak
Pembahasan dalam penelitian ini dilakukan untuk mengetahui pelaksanaan pengawasan shahibul maal yang dilakukan dalam mengurangi masalah pembiayaan. Sesuai dengan ketentuan Bank Indonesia bahwa jumlah pembiayaan bermasalah yang dicairkan tidak melebihi 5\%. Sedangkan rata-rata per tahun jumlah masalah pembiayaan shahibul maal lebih besar dari 5\%, jadi dari 5\%. Untuk dapat melakukan penyelamatan pembiayaan bermasalah, beberapa upaya perlu dilakukan seperti penjadwalan ulang untuk memungkinkan kelonggaran ke Shahibul Maal untuk membayar pembiayaan yang telah jatuh tempo dengan menunda tanggal jatuh tempo. Kemudian susuk kembali persyaratan pembiayaan untuk memperkuat posisi tawar dengan nasabah dengan mengkaji isi kesepakatan pembiayaan bila diperlukan plus atau minus. Dan memperbaiki struktur pendanaan (rekapitulasi) dan organisasi bisnis, membantu memperbaiki kondisi dan likuiditas keuangan Shahibul Maal. Dengan demikian sedikit demi sedikit Shahibul Maal mampu melunasi pembiayaan bermasalahnya.
\end{abstract}

Kata kunci: Pemantauan, Pembiayaan Murabahah, Pembiayaan Bermasalah 


\section{A. INRODUCTION}

The current Islamic economy has grown rapidly. This can be seen from the rise of economic institutions both business and finance that carry out its business with the Islamic Shari'a. Some of these institutions include sharia banks, sharia insurance, sharia hotels, etc. Islamic economics has also proven able to advance the economy, as has been proven in Islamic Caliphate, where at that time the western countries are experiencing dark ages (dark ages). The golden age is declining as a result of the distortion of Islamic sharia whose values are very universal. Therefore, the exploration of values and methods and how to manage the economy sharia becomes important. Moreover, the demand for this method is the needs of people and society.

The reliability of the Islamic economy has also been proven in Indonesia, at least during the time of the motetary crisis that brought on the economic and multidimensional crisis, the sharia banks were able to survive and avoid the banking crisis and the banking recapitalization. This is because the syariah system does not allow for a negative spread. Islam is a syamil religion. And organize all aspects of human life. But in the ever-changing problems, Islam only regulates it outline / globally. Economic (business) and political issues are areas of great change. In this case there are three things that can be used as the basis of reference: the Hadith which reads: "Kalian lebih mengetahui urusan dunia kalian" (Muslim, from Siti Aisyah and Anas This means for technical matters not regulated in the Qur'an and Hadith, are welcome to carry out in their own way, in accordance with the principle: "basically all is permitted, except for which is prohibited" The announcement and immutability of Islamiyah.

Banking system, managed based on the principle of profit sharing. The management of profit-sharing system will benefit every society and bank, as well as highlight the aspects of fairness to transact, ethical investment, putting together the values of togetherness and brotherhood that accomplish will affect the financial performance of the bank. By providing various promotional activities and banking services, banking is a credible alternative and can be enjoyed by all Indonesian people. (Locander, W.B., F. H, D.L \& J.Stuart 20I7).

The importance of functioning and the role of the banking system, through the Act. No. 2I of 2008 on sharia banking issued on July I6, 2008, will affect the development of the banking industry which in turn will drive its growth more quickly. This can be seen from the average growth of turnover more than $65 \%$ per year in the last 5 years, it is expected that the role of sharia banking industry will support an increasingly significant economy. (Suryanto, T. 2017). 
One of the factors that led to the development of sharia banking industry that impact on economic development in Indonesia is through the payment of profit sharing. Where the system for the results applied in Islamic banking is very different from the system of interest. The system for interest can be earned at the earliest advantage, by calculating the amount of interest expense from the funds deposited and borrowed. While the profit sharing system provision of profits will be determined based on the amount of profit multiples of the results of the business, the superior with the principle of sale and purchase with mudharabah is cooperation between two parties, where the first party provides all the capital and the other party becomes the manager. Profits are divided according to the agreement set forth in the contract and if the loss will be borne by the owner of the capital, as long as the loss is not a result of management's negligence. Whereas if the negligence of management will be made the remaining collateral that has been pledged to the Bank Syariah concerned.

\section{B. MURABAHAH IN ISLAMIC ECONOMICS}

In the Islamic economic concept, two kinds of doctrine and law: first, things that are fixed and binding from time to time forever, such as those who are entitled to receive zakat, heirs, and unlawful usury. Second, things that accept change and are subject to the development of the times. Here is the opening of the door of ijtihad and dissent of the mujtahids. Islamic economics can be likened to a house consisting of roofs, poles, and foundations. So it is with Islamic economics.

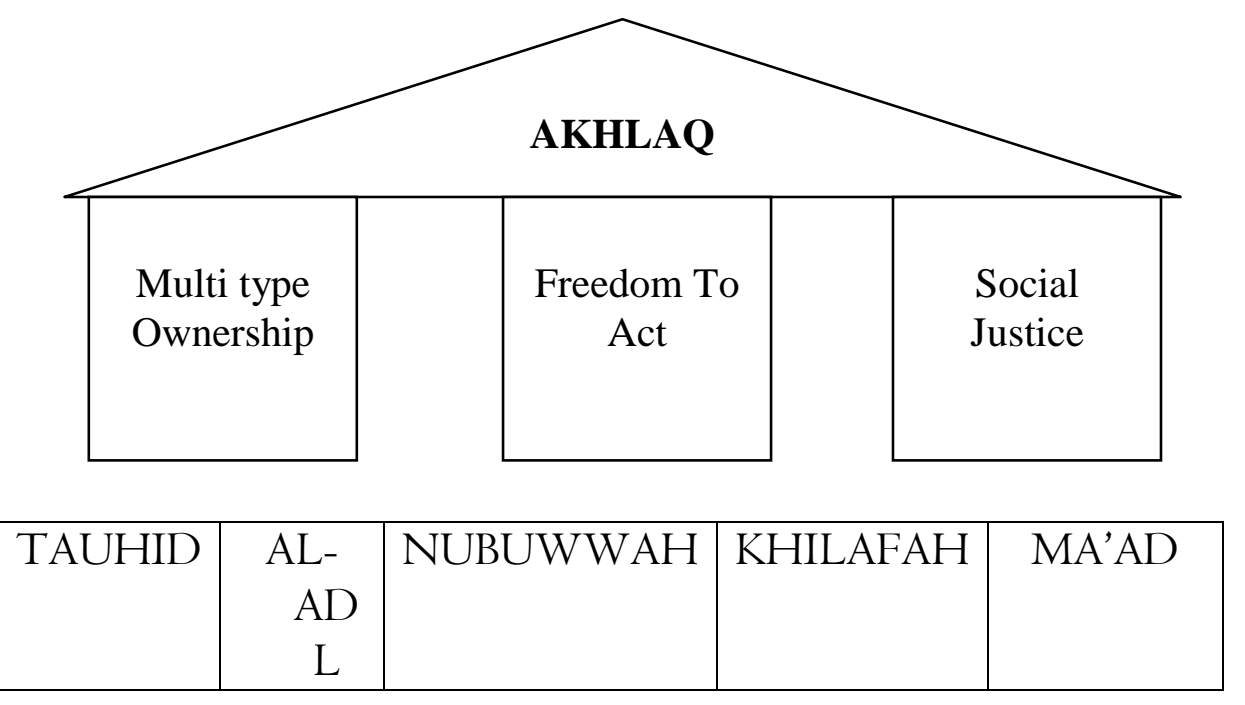


Ash Shawi (200I: 90-9I) said that the term for murabahah transactions according to fiqih is ba'I al murabahah (sale and purchase murabahah) which is included in the type of trading trustah, that is buying and selling where the seller notify the price of the principal.

According Karim (2010: 98) in Islamic bank murabaha (al-bai'bitsaman ajil) better known as murabaha alone. Simply put, murabahah means a sale of goods at the merchandise plus an agreed advantage. For example, someone buys the item and then sells it back with a certain profit. How much of such profit may be expressed in certain rupiah nominal or in the form of a percentage of the purchase price, for example $10 \%$ or $20 \%$. While Muhammad (200I: 42) said that the recognition and measurement murabaha in accordance with PSAK No. I02, murabaha is to sell goods at the selling price of the acquisition price plus the agreed profit and the seller must disclose the cost of the item to the buyer.

According to Lubis (2004: 62), murabahah financing is an agreement between the bank and its customers. The agreement is in the form of financing the purchase of something that is needed by the customer. The customer will pay to the bank within the agreed time (at maturity date) and this is typically a short financing. Murabaha in its original sense according to Islam is "is simply a sale" of buying and selling (Widodo, 1999: 19). In sharia banking operations the term used is not a sale and purchase of murabahah, but modified by the term "murabahah receivables". According to Bank Indonesia Regulation Number 5/7 / PBI / 2003, dated May 19, 2003, the financing is claims arising from sale and purchase transactions based on murabahah, salam, istishna and or lease based on ijarah agreement. While financing is the provision of funds and / or claims based on mudharabah or musyarakah or other financing based on the principle of profit sharing (Bank Indonesia 2003: I7-I8).

Murabahah is the sale and purchase of an item with deferred payment. That is, new buyers pay at maturity with the selling price of the cost of goods plus agreed benefits (Widodo, et al. 1999: 49). Murabaha is a sale and purchase agreement between the bank and the customer in which the sharia bank purchases the required goods by the customer and then sells it to the respective customer at the acquisition price plus the agreed margin / profit between the syariah bank and the customer (Muhammad, 200I: I89).

Murabahah described in the list of books of the DSN fatwa (2003: 3II) is to sell an item by confirming its purchase price to the buyer and the buyer pays it at a more profit. While in SFAS 59 concerning Accounting for Islamic Banking paragraph 52 it is explained that murabaha is a contract of sale and purchase of 
goods by stating the price of acquisition and profit (margin) agreed by the seller and the buyer. So in short, murabaha is a contract of sale and purchase of goods by stating the price of acquisition and profit (margin) agreed by the seller and the buyer. This contract is one form of natural certainty contracts, because in murabaha determined how the required rate of profit (profit to be obtained). In the murabaha bai'al, the seller must notify the price of the product he purchases and determine a profit rate in addition. Murabahah can be made for purchase by ordering system. In the book of al-Umm, Imam Shafi'i named this transaction with the term al-amir bi al-syira. In this case the prospective buyer or subscriber can order to someone (call it buyer) to buy a certain item he wants. Both parties make an agreement on the goods and possible price of origin of the purchase that is still able to bear the customer. After that, both parties also have to agree on some benefits or additional to be paid subscribers. Sale and purchase of both parties is done after the goods are in the hands of the buyer. Sale and purchase is required based on the consensus of the Muslims, because the life of mankind can not be erect without any buying and selling.

Figure 2.

Murabahah Financing Scheme

Negotiation \& Terms

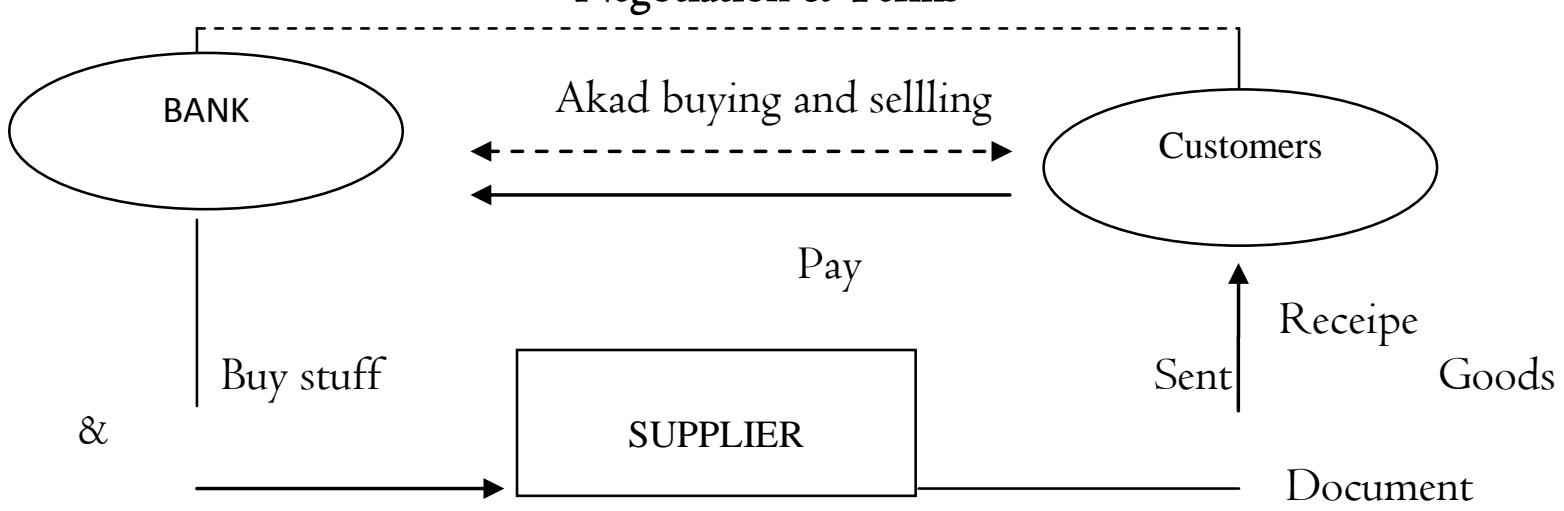

(Antonio, 200I:I07)

Information :

I. There is an agreement between the bank and the customer to enter into agreements or negotiations and requirements

2. After negotiations and then make an agreement on how the contract of sale and purchasen between the two sides. 
3. From the Bank's side commences activities in the form of purchasing goods to the seller for the customer on behalf of the bank.

4. On behalf of the seller's bank sending the goods to the customer that has been indicated by the bank.

5. The Customer shall receive goods and agreement documents from the seller on behalf of the bank

6. After the customer receives goods and documents from the seller. Thus, the last obligation of the customer to pay the goods to the Bank in accordance with the initial agreement.

According to Rivai Veitzal and Andria Permata Veithzal, the types of financing controls are:

I. On desk monitoring, administrative financing monitoring through administrative instruments, such as reports, financial statements, completeness of documents, and third party information.

2. On site monitoring, ie monitoring the financing directly to the field (customer), either in part, in whole, or in particular or in a particular case to prove the implementation of the financing policy, or thoroughly whether there is any deviation occurring on agreed terms of lending.

3. Excption monitoring, ie monitoring of financing by putting pressure on things that are not running well and things that have been run in accordance with terms of lending, reduced intensity.

According Azhari Ismul (20I2), the cause of problematic financing is due to financial difficulties faced by customers. Causes of financial difficulties of the customer company. To determine the steps that need to be taken in facing the financing of jams first need to be investigated the causes of congestion. When congestion is caused by external factors such as natural disasters, banks no longer need to conduct further analysis. What is necessary is how to help the customer to get immediate reimbursement from the insurance company. What needs to be investigated is internal factors, namely that occurs due to managerial causes. If the bank has been careful monitoring from month to month, from year to year, then the congestion arises, a bit more related to the weakness of the supervision itself. Unless supervisory activities have been properly implemented, financial difficulties are still occurring, it is worth investigating the causes of the bottlenecks in more depth. Perhaps the difficulty is deliberate by the management of the company, which means the entrepreneur has done things that are not honest. For example, with entrepreneurs transferring the use of funds available for other business activities beyond the agreed object financing. (Arifin, 2002: 243-246). 
Say Allah SWT: "Apabila mereka mengalami kesempitan, maka hendaknya diberikan kelonggaran..." (QS.2:280). Apabila didapati sesuatu barang di sisinya dan belum berubah, maka barang itu adalah menjadi hak pemiliknya yang telah menjadi kepadanya” (HR Imam Muslim \& Nasa'i).

From Ka'ab bin Malik, "The Prophet SAW once confiscated Muadz's property and he sold it to pay its debts" (Imam Daruquthi's HR) (Arifin, 2002: 246)

\section{RESEARCH METHODS}

The location of the research was conducted at Bank Muamalat Gorontalo. The reason the researchers because the bank is operating on the basis of Islamic sharia and managing funds for the welfare of the ummah. Types and resources used in this study are data obtained directly from the subject of research by using measuring devices or data taking tools directly on the subject as a source of information sought. (Arikunto, 2002: 236). Data collection methods used in this study are interviews and documentation (Saebani, 2008: 190). Data analysis is the process of arranging the sequence of data and organizing into a pattern, categories and units of the basic description so that it is easier to read and interpret (Moleong, 2005: II2). The data analysis used in this research is qualitative, with the intention that each data obtained from the field is collected and then classified by lriteria. With reference to the problem formulation.

\section{RESEARCH RESULT}

Financing is the provision of funding facilities to support planned investments based on agreements between banks and other parties requiring parties financed for refunds or invoices after a certain period of time in return or for profit sharing.

Based on the above explanation, there are some verses that discuss in general about the sale and purchase of Murabahah and trade in the Qur'an and sunnah that can be used as a reference and the foundation are:
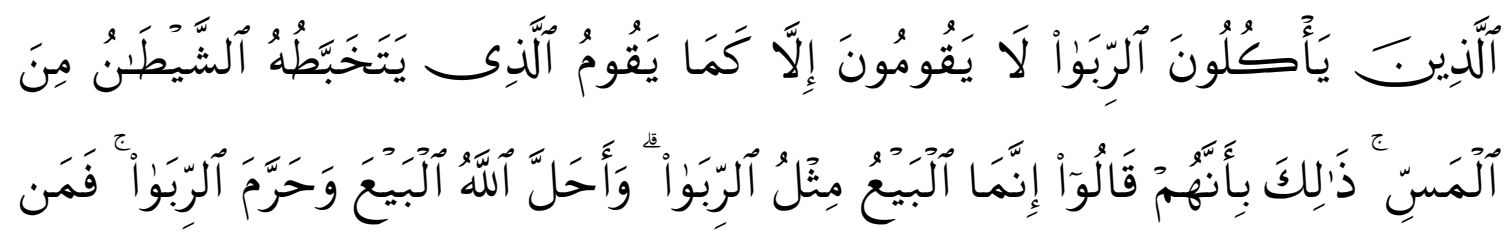


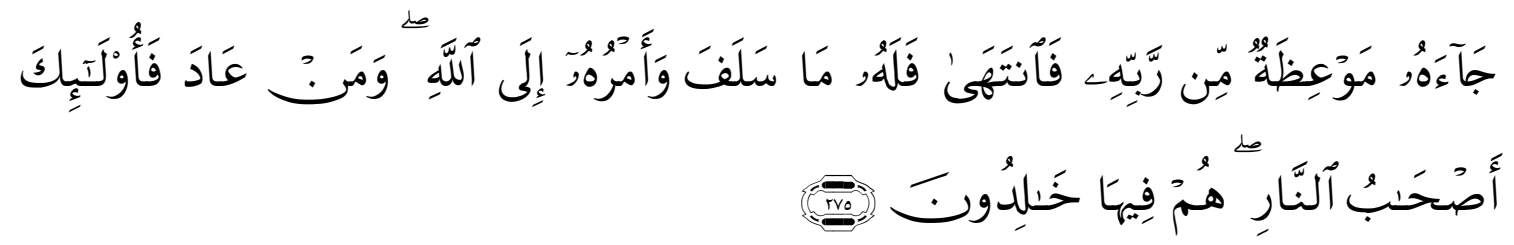

"Padahal Allah telah menghalalkan jual beli dan mengharamkan riba."

(Qs. Al- Baqarah: 275).

Al-Qur'an:

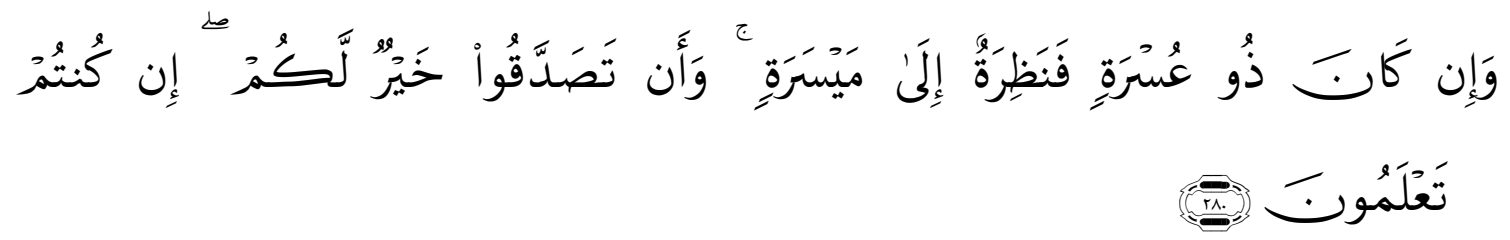

280. dan jika (orang yang berhutang itu) dalam kesukaran, Maka berilah tangguh sampai Dia berkelapangan. dan menyedekahkan (sebagian atau semua utang) itu, lebih baik bagimu, jika kamu mengetahui.

According to Imam Syafi'I declared that if someone told others, "Buy something for me and then I will give you an advantage. "Then, according to him this kind of buying and selling is legitimate. In Indonesia, Murabahah has been allowed (halal) with the release of the National Sharia Council Fatwa Majelis Ulama Indonesia No: 04 DSN-MUI / IV / 2000. In the fatwa mentioned that one reason menghalalkannya murabaha is because many people require the distribution of funds from Islamic banks based on the principle of buying and selling. The community also needs assistance in order to establish and improve the welfare of various activities, so sharia banks need to have murabaha facilities for those who need them.

Thus, for these reasons, murabahah financing is considered valid (Halal). Implementation of financing distribution begins by prospective customers apply for financing. Based on the procedure of financing submission, has implemented the mechanism of Submission of Financing in accordance with Sharia Principles namely, Shahibul Maal (Customer) and apply for financing.

The financing scheme mechanism is intended to determine whether or not Shahibul Maal candidates (customers) receive financing. Based on the eligibility criteria of candidate Shahibul Maal before receiving financing that is, (I) character or character of prospective customer, (2) ability of his / her capacity / capacity, 
and

Arrears.

This assessment is undertaken to confirm that the business to be funded is really a business that does not violate sharia in accordance with the Fatwa DSN "Managers must not violate Islamic sharia law in its actions relating to Murabahah."

Payment approval mechanism based on the results of feasibility analysis of financing pembarian. Can be paid in cash or tough.

Based on the arguments in the Qur'an and Al-Hadith:

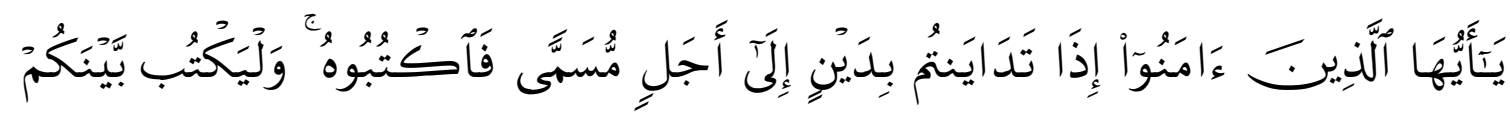

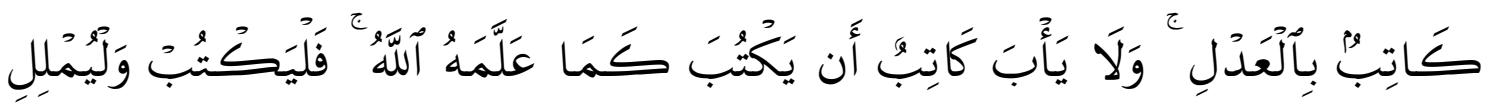

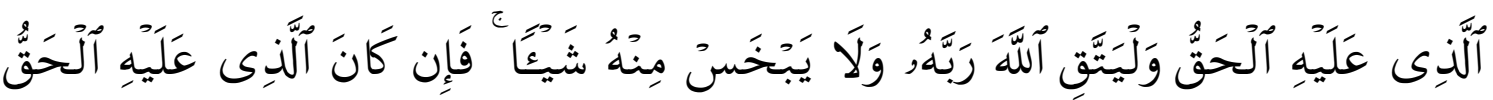

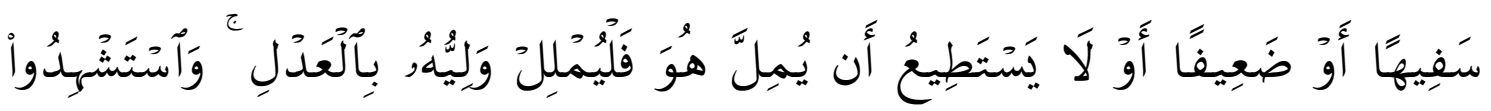

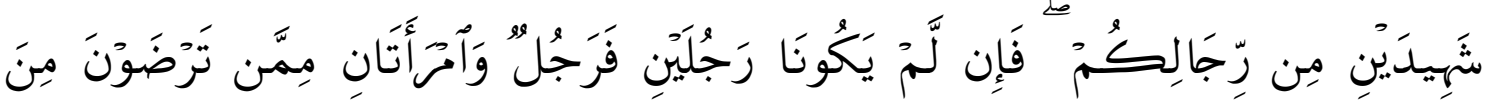

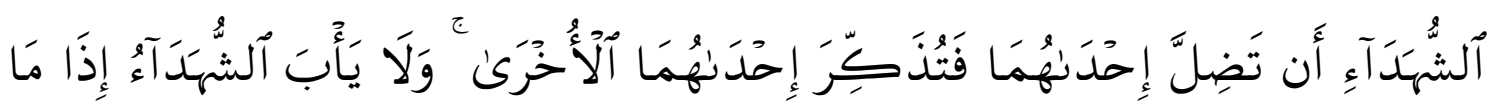

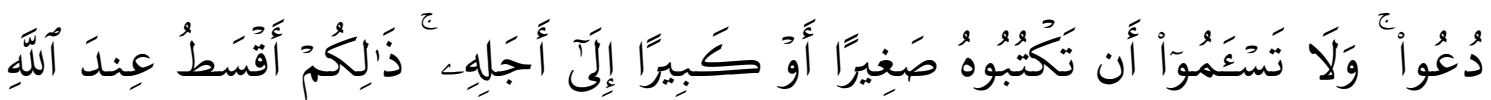

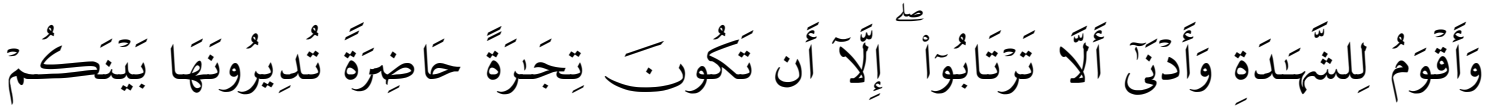

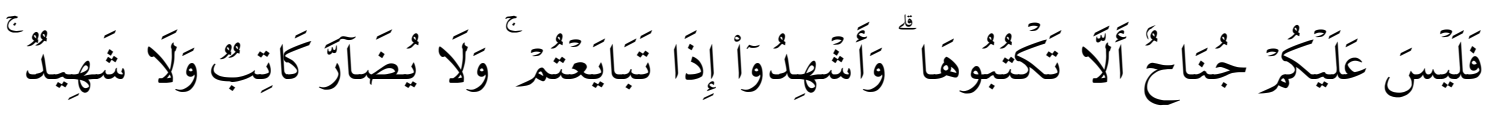

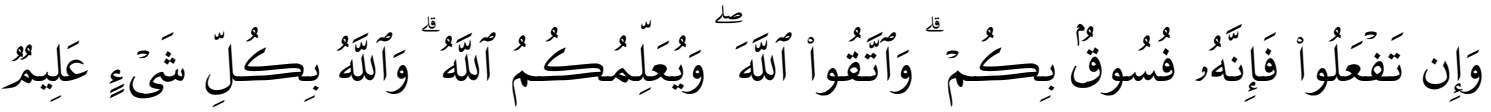

282. Hai orang-orang yang beriman, apabila kamu bermu'amalah[I79] tidak secara tunai untuk waktu yang ditentukan, hendaklah kamu menuliskannya. dan hendaklah seorang penulis di antara kamu menuliskannya dengan benar. dan 
janganlah penulis enggan menuliskannya sebagaimana Allah mengajarkannya, meka hendaklah ia menulis, dan hendaklah orang yang berhutang itu mengimlakkan (apa yang akan ditulis itu), dan hendaklah ia bertakwa kepada Allah Tuhannya, dan janganlah ia mengurangi sedikitpun daripada hutangnya. jika yang berhutang itu orang yang lemah akalnya atau lemah (keadaannya) atau Dia sendiri tidak mampu mengimlakkan, Maka hendaklah walinya mengimlakkan dengan jujur. dan persaksikanlah dengan dua orang saksi dari orang-orang lelaki (di antaramu). jika tak ada dua oang lelaki, Maka (boleh) seorang lelaki dan dua orang perempuan dari saksi-saksi yang kamu ridhai, supaya jika seorang lupa Maka yang seorang mengingatkannya. janganlah saksi-saksi itu enggan (memberi keterangan) apabila mereka dipanggil; dan janganlah kamu jemu menulis hutang itu, baik kecil maupun besar sampai batas waktu membayarnya. yang demikian itu, lebih adil di sisi Allah dan lebih menguatkan persaksian dan lebih dekat kepada tidak (menimbulkan) keraguanmu. (Tulislah mu'amalahmu itu), kecuali jika mu'amalah itu perdagangan tunai yang kamu jalankan di antara kamu, Maka tidak ada dosa bagi kamu, (jika) kamu tidak menulisnya. dan persaksikanlah apabila kamu berjual beli; dan janganlah penulis dan saksi saling sulit menyulitkan. jika kamu lakukan (yang demikian), Maka Sesungguhnya hal itu adalah suatu kefasikan pada dirimu. dan bertakwalah kepada Allah; Allah mengajarmu; dan Allah Maha mengetahui segala sesuatu.

Supervision / control of financing is basically an effort to secure financing that has been provided by continuously monitoring / monitoring and continue to follow the company's path either directly or indirectly. And also do administrative supervision to prospective customers, and provide advice or advice and consultation for the company to run well so that the return of financing will also run well too.

Based on the above explanation, there are some verses that discuss about the supervision of them:

Al-Qur'an:

"Dan sesungguhnya kebanyakan dari orang-orang yang berserikat itu sebahagian mereka berbuat zalim kepada sebahagian yang lain, kecuali orang-orang yang beriman dan mengerjakan amal saleh; dan amat sedikitlah mereka ini." (Qs. Shad: 24 ).

Al-Hadist: Dari Abu Hurairah, Rasulullah SAW bersabda: "sesungguhnya Allah SWT berfirman: "Aku pihak ketiga dari orang yang berserikat selama salah satunya tidak menghianati temannya." (H.R. abu Dawud No. 2939, kitab Al Buyu dan Hakim).

Based on Al-Qur'an and Hadith supervision to be able to minimize the opportunities of financial irregularities that could harm. To rescue problematic financing, several efforts were made, namely (I) Rescheduling, (2) Reordering 
Financing Requirements, (3) Reorganization and Recapitulation. Based on the above explanation, as for the foundation of shari'ah that can support efforts to rescue problematic financing.

From the quoted verses of Al-Qur'an and Al-Hadist above always underlined the importance of alms and guidance of the need for tolerance to the customer when facing the customer is experiencing difficulties (in the real sense) to repay his obligations.

\section{E. CONCLUTION}

Efforts to overcome the problematic financing is to conduct the implementation of administrative payment supervision, direct supervision of funds to the field and monitoring in the implementation of financing shahibul maal.

To be able to rescue the troubled financing, several other attempts such as rescheduling to allow leeway to Shahibul Maal to pay its due financing by delaying the maturity date. Then re-arrange the financing requirements to strengthen the bargaining position with the customer by reviewing the contents of the financing agreement when necessary plus or minus. And improving the funding structure (recapitulation) and business organizations, can help improve the condition and financial liquidity of Shahibul Maal. Thus little by little Shahibul Maal was able to pay off his troubled

\section{REFERENCES}

Antonio, Muhammad Syafi'I, 200I, Bank Syariah Dari Teori Ke Praktik. Gema Insani Press; Jakarta.

Arifin, Zainul, 2002, Dasar-Dasar Manajemen Bank Syariah. Penerbit AlvaBet Anggota IKAPI.

Arikunto, Suharsimi, 2002, Prosedur Penelitian Suatu Pendekatan Praktek. Rineka Cipta, Jakarta

Ash-Shawi, Shalah dan Abdullah Al-Mushlih, 200I, Fikih Ekonomi Keuangan Islam. Darul Haq, Jakarta.

Azhari Ismul, 2012, Bank dan Lembaga Keuangan, Kesehatan Bank, http://ekonomyslam.blogspot.com/2010/08/pengertian-bmt.html : di akses tanggal 02 Agustus 2012, 20:2I

DSN MUI, 2000, Himpunan Fatwa DSN : Keputusan DSN No. 04 Tahun 2000, tentang Ketentuan Hukum Murabahah. 
Murabahah Financing And Its Implementation For the Economic Empowerment of the Ummah (Abdul Rahmat)

DSN MUI, 2003, Himpunan Fatwa DSN : Keputusan DSN No. 03 Tahun 2000, tentang Petunjuk Pelaksanaan Penetapan Anggota Dewan Pegawas Syariah Pada Lembaga Keuangan Syariah, edisi kedua, PT. Intermasa, Jakarta

Hisyam Bin Muhammad, Hafidzullah Sid Aali Barghasy, 2002. Hukum Jual Beli Secara Kredit, Hukum dan Kode Etikanya Menurut Syari'at Islam. Solo: AtTibyan.

Karim, Adiwarman A, 1995. Ekonomi Islam Sebagai Suatu Kajian Kontemporer. Gema Insani Press: Jakarta.

Kasmir, 2006. Dasar-dasar Perkreditan. Penerbit: PT. RajaGrafindo Persada, Jakarta.

Locander, W.B., F. Hamilton, D.Ladik \& J.Stuart. Developing aleadership- rich culture: The missing link to creating a market-focusedorganization ${ }^{r}$ urnal of Market-Focused Management. Vol. 5, pp. I49-I63.20I7.

Lubis, Suhrawardi K, 2004, Human Ekonomi Islam. Penerbit: Sinar Grafika, Jakarta.

Moleong, Lexy J, 2005. Metode Penelitian Kualitatif, edisi revisi, Penerbit: PT. Remaja Rosdakarya, Bandung.

Muhammad dan Dwi Suwiknyo, 2009, Akuntansi Perbankan Syariah. Penerbit: Trust Media, Yogyakarta

Muhammad Nur, 2009, Pelaksanaan Pemberian Pembiayaan Mudharabah Kepada Koperasi Studi Pada Bank Muamalat Cabang Medan. Tesis USU Medan

Muhammad, 200I. Manajemen Pembiayaan Bank Syariah. Penerbit UUP-AMP YKPN, Yogyakarta

Pernyataan Standar Akuntansi Keuangan. PSAK No. 59 Akuntansi Perbankan Syari'ah. Mei 2002. Dewan Standar Akuntansi Keuangan Ikatan Akuntansi Indonesia (IAI). Jakarta.

Rifqi, Muhammad, 2008, Akuntansi Keuangan Syariah, Konsep dan Implementasi PSAK Syariah, edisi kesatu, Penerbit : P3EI Press, Yogyakarta

Suryanto, T. 2017. Consequences of Going Concern Opinion for Financial Reports of Business Firms and Capital Markets with Auditor Reputation as a Moderation Variable - An Experimental Study. European Research Studies Journal 20(2A)

UU. No. 2I tahun 2008 tentang perbankan syariah yang terbit tanggal I6 Juli 2008

Veithzal Rivai, Andria Permata Veithzal, 2006. Credit Management Handbook, Jakarta: PT. RajaGrafindo Persada. 
IKONOMIKA

Volume 2, No 2 (2017)

https://ejournal.radenintan.ac.id/index.php/ikonomika 